\title{
ANALISIS KOHESI DALAM KARANGAN SISWA KELAS VIII SMP MUHAMMADIYAH TAKKALASI KABUPATEN BARRU
}

\author{
Iskandar $^{1}$ Sri Wahyuni ${ }^{2}$ \\ Fakultas Keguruan dan Ilmu Pendidikan,Univeritas Muhammadiyah Makassar \\ iskandar@gmail.com \\ Pendidikan Bahasa dan Sastra Indonesia,Univeritas Muhammadiyah Makassar
}

\begin{abstract}
This study aimed to describe the use of cohesion in the junior class VIII student essay MuhammadiyahTakkalasi Barru terms of discourse analysis. This research is descriptive quantitative analysis design cohesion. From the analysis obtained by tabulating the frequency and percentage analysis results. Efforts to achieve these objectives pursued by analysis on 25 samples of fruit bouquets of all eighth grade students of SMP Muhammadiyah Takkalasi Barru. The type of cohesion that used by students seem fraction only use four, five, nine to ten types and mostly used six, seven or eight species. Frequency of use of the types of cohesion was found to differ from each other. The average frequency of use of cohesion in general distribution found from 0.28 to 20.04, while the level of discourse cohesion proportion of students found an average of $0.38 \%-48.57 \%$. With this fact can be seen that the level of harmony cohesion student remains low or in sufficient to serve as the foundation of a coherent essay. Based on these findings, it suggested that the results used as input for the reader to better understand the discourse primarily on the theory of cohesion in analyzing an essay / article, in order to improve the quality of their writing specifically for students of class VIII SMP Muhammadiyah Takkalasi Barru and all levels students in general, and the need for cohesion in a research essay by the same method, the same language, the different types of discourse.
\end{abstract} Keywords: bouquet, analysis of cohesion.

\begin{abstract}
Abstrak
Penelitian ini bertujuan untuk mendeskripsikan penggunaan kohesi dalam karangan siswa kelas VIII SMP MuhammadiyahTakkalasi Kabupaten Barru ditinjau dari analisis wacana. Penelitian ini adalah penelitian deskriptif kuantitatif dengan rancangan analisis kohesi. Dari analisis tersebut diperoleh tabulasi frekuensi dan persentase hasil analisis. Usaha untuk mencapai tujuan tersebut ditempuh dengan melakukan analisis pada sampel 25 buah karangan dari seluruh siswa kelas VIII SMP Muhammadiyah Takkalasi Kabupaten Barru. Jenis kohesi yang digunakan oleh siswa tampaknya sebagian kecil hanya menggunakan empat, lima, Sembilan sampai sepuluh jenis dan sebagian besar menggunakan enam, tujuh sampai delapan jenis. Frekuensi penggunaan jenis-jenis kohesi ditemukan berbeda satu sama lain. Frekuensi rata-rata dari penggunaan distribusi kohesi secara umum ditemukan dari 0,28-20,04, sedangkan tingkat proporsi kohesi wacana siswa ditemukan rata-rata 0,38\%-48,57\%. Dengan kenyataan tersebut dapat diketahui bahwa tingkat keharmonisan kohesi siswa masih rendah atau belum memadai untuk dijadikan pondasi karangan yang koheren. Berdasarkan temuan penelitian ini, disarankan agar hasilnya dijadikan sebagai bahan masukan bagi pembaca agar dapat lebih memahami wacana utamanya mengenai teori kohesi dalam menganalisis suatu karangan/tulisan, dalam rangka meningkatkan kualitas tulisan mereka secara khusus bagi pelajar kelas VIII SMP Muhammadiyah Takkalasi Kabupaten Barru dan seluruh tingkatan pelajar pada umumnya, dan perlunya dilakukan penelitian kohesi dalam karangan dengan metode yang sama, bahasa yang sama, pada jenis wacana yang berbeda.
\end{abstract}


Kata kunci: karangan, analisis kohesi.

\section{PENDAHULUAN}

Pada hakikatnya belajar bahasa adalah belajar berkomunikasi. Oleh karena itu, pembelajaran bahasa indonesia diarahkan untuk meningkatkan kemampuan siswa untuk berkomunikasi secara lisan maupun secara tulisan. Salah satu wujud kemampuan dari siswa sesuai dengan GBPP Kurikulum Sekolah Lanjutan Tingkat Pertama adalah kemampuan membuat wacana. Penekanan pembelajaran wacana tersebut bukan pada pembahasan wacana itu sendiri, melainkan pada pengembangan melalui hubungan antarkata dengan kalimat antar kalimat dengan paragraf dan antarparagraf dalam wacana yang utuh atau koheren dengan piranti-pirantinya seperti penggunaan alatalat kohesi secara tepat.

Penyusunan wacana yang ideal mengandung seperangkat proposisi-proposisi yang saling berhubungan untuk menghasilkan suatu rasa keberpaduan atau kohesi. Selain itu, juga dibutuhkan keteraturan dan kerapian susunan yang menimbulkan rasa koherensi.

Kalau dikaitkan dengan kemampuan berbahasa, menulis/mengarang merupakan hal yang sangat penting, karena itu tidak hanya diukur dari kesanggupan menulis lambang secara otografis, tetapi juga dapat menggunakan kosakata, tanda baca, dan menyusun karangan atau wacana.

Hal demikian mungkin disebabkan oleh adanya faktor-faktor yang mempengaruhi kegiatan menulis tersebut sehingga sulit untuk dikuasai. Faktor-faktor itu seperti faktor kemampuan menulis yang menghendaki penggunaan berbagai unsur di luar bahasa yang akan menjadi isi karangan. Kemudian analisis hubungan-hubungan kohesif dalam karangan yang dimaksudkan untuk mengetahui bagaimana perencanaan penulis menentukan hal yang ingin dikatakannya. Di samping itu, dapat diketahui apakah yang disampaikan itu tertulis dengan baik atau tidak. Keterkaitan yang disertakan dalam menafsirkan teks pada suatu karangan tidak saja didasarkan pada hubungan antar kata-kata dalam teks/karangan, tetapi terdapat faktor-faktor yang menjadi tuntutan yang membedakan teks-teks yang berkaitan yakni faktor koherensi.

Pada kenyataannya sekarang kemampuan siswa dalam karangan kohesif dan koherensif belum dipakai secara menyeluruh. Begitu pula dengan masalah kurang difungsikannya satu aspek pendidikan yang sangat penting yaitu pembuatan wacana yang koheren. Misalnya dalam menilai latihan mengarang siswa, guru hanya menyoroti bahasa dalam karangan tersebut bukan mempertimbangkan padu atau tidaknya sebuah karangan, sehingga dalam pencapaian tujuan akhir dalam evaluasi karangan secara ideal seperti yang diungkap di atas tidak dapat diperoleh. Penyusunan wacana yang ideal adalah penyusunan wacana yang sudah disusun dengan menggunakan bahasa yang baik dan mudah dipahami.

Berdasarkan uraian di atas, maka penulis tertarik untuk meneliti kemampuan siswa SMP Muhammadiyah Takkalasi kab. Barru utamanya yang duduk di kelas VIII SMP sebagai salah satu pemakai bahasa dalam memahami penggunaan kohesi dan koherensi melalui tulisan ditinjau dari analisis wacana sebab siswa yang telah menduduki jenjang pendidikan tingkat lanjut sebelum masuk tingkat menengah atas sudah pernah mendapatkan pengajaran menulis bahkan sudah terlatih untuk menulis mulai SD sampai SMP. 
Dalam Tata Bahasa Baku Bahasa Indonesia (Hasan Alwi dkk, 2000: 427) dijelaskan bahwa "Kohesi merupakan hubungan perkaitan antarproposisi yang dinyatakan secara eksplisit oleh unsur-unsur gramatiakal dan semantik dalam kalimatkalimat yang membentuk wacana".

Selain itu, Ramlan (1993:10) mengemukakan bahwa "Kohesi atau kepaduan dibidang bentuk suatu wacana merupakan kumpulan dari sejumlah kalimat yang saling berkaitan sehingga membentuk satu kesatuan."Defenisi serupa di utarakan pula oleh Sumadi dkk (1998: 4) bahwa kohesi adalah "Hubungan antara kalimat yang membangun keutuhan wacana".

Sebagai kesimpulan dari ketiga pendapat di atas adalah bahwa kohesi merupakan hubungan kalimat-kalimat yang lengkap yang mengandung makna sehingga membentuk satu kesatuan yang mudah dipahami.

Junus (2002:49-61) mengemukakan bahwa hubungan kohesif yang merupakan dasar koheren dapat diwujudkan dalam wacana dengan berbagai unsur, sebagai berikut:

1) Dengan hubungan sebab akibat;

2) Dengan huibungan unsur-unsur tertentu, seperti pertentangan, tujuan, pengecualian, konsesif dan berlebihan;

3) Dengan pengulangan kata atau frasa;

4) Dengan Ko-referensi ( merujuk ke acuan yang sama atau kereferensi yang sama);

5) Dengan menuju ke spesies yang sama atau kumpulan yang sama;

6) Dengan kataforis dan anaforis;

7) Dengan metafora yang mengacu kepada sesuatu yang diibaratkan kepada sesuatu yang lain;

8) Dengan ellipsis ( peniadaan kata-kata);

9) Hubungan leksikal atau hiponimi;

10) Hubungan bagian keutuhan; dan

11) Dengan judul yang deskriftifdan singkat.
Dari kesebelas unsur-unsur kohesi di atas, beberapa di antaranya sama dengan unsur-unsur koherensi. Berikut ini dituliskan beberapa unsur yang berbeda, yaitu: hubungan sebab akibat, hubungan koreferensi, unsur yang mendukung ke spesies yang sama, unsur kataforis dan anaforis, ellipsis, unsur leksikal atau hiponiomi dan dengan judul deskriftif yang singkat.

Berdasarkan unsur-unsur di atas, dapat dikemukakan sebuah contoh sebagai berikut:

a) Bilal dan Fajar kawannya pergi ke kampus, karena Fajar kawannya harus mendaftar ulang.

b) Hari mendung akan hujan, Sering hujan akan mengakibatkan banjir, Banjir akan menimbulkan wabah penyakit.

Wacana pada (a) dikatakan kohesif karena terdapat pengulangan unsur yang sama yaitu 'Fajar kawannya'. Begitu pula dengan wacana (b) terdapat pula unsur pengulangan leksikal, seperti 'hujan' dan 'banjir'.

Halliday dan Hasan (1976) yang mengemukakan bahwa sarana-sarana kohesi yang terperinci dalam karya mereka yang berjudul Cohession in English, mereka mengelompokkan kohesi ke dalam lima kategori, yaitu:

1) Pronomina (kata ganti) yang meliputi kata ganti orang, petunjuk, penanya, penghubung, tak tentu, kata ganti perbandingan (komparatif).

2) Subtitusi ( penggantian) yang merupakan proses atau hasil penggantian unsur bahasa oleh unsur lain dalam satuan yang lebih besar untuk memperoleh unsur-unsur pembeda atau untuk menjelaskan sesuatu struktur tertentu (Kridalaksana; 1993: 204)

3) Ellipsis adalah peniadaan kata atau satuan lain yang wujud asalnya dapat diramalkan 
dari konteks bahasa atau konteks luar bahasa (Kridalaksana; 1993:50)

4) Konjungsi merupakan partikel yang dipergunakan untuk menggabungkan kata dengan kata, frasa dengan frasa, klausa dengan klausa, kalimat dengan kalimat, atau paragraf dengan paragraf (Kridalaksana; 1993: 117)

5) Leksikal merupakan kohesi leksikal yang dapat diperole dengan cara memilih kosakata yang serasi

Menurut Asnaeni (1998: 39-40), beberapa pakar mengemukakan eksistensi kohesi dalam wacana siswa, antara lain: 1) Merujuk pada Khalil yang mengadakan studi tentang kohesi dalam bahasa Arab EFL dalam pelajaran menulis. Dia melaporkan bahwa "pengulangan tampak frekuensinya lebih tinggi dalam penulisan penghubung yang kedua, referensi yang ketiga, kolokasi yang keempat, dan kata ganti yang kelima". 2) Selanjutnya, hal serupa dikemukakan pula oleh Neuner dalam studinya tentang kohesi dalam pengajaran karangan. Dia melukiskan bahwa "Kohesi leksikal khususnya pada pengulangan pada pernyataan yang sama tampak berkalai-kali dalam karangan pelajar”.3) Sedangkan Connor (1984) mengungkapkan penemuannya tentang pengulangan leksikal yang frekuensinya $84 \%$, sebaliknya kolokasi yang tingkat frekuensinya sangat kurang.

Dari ketiga pendapat di atas dapat disimpulkan bahwa kohesi leksikal secara pengulangan pada pernyataan yang sama mengangkat frekuensi yang lebih tinggi dalam wacana siswa.

$$
\text { Halliday dan Hasan (1980), }
$$

membahas tentang kohesi/kepaduan dalam bahasa Inggris. Setelah itu, maka melahirkan alat analisis kohesi/kepaduan. Prosedur telah diimplementasikan beberapa pelajaran seperti Crow Hurs, Neuner, walaupun tidak secara eksplisit. Prosedur seperti tercantum di bawah ini:

1) Identifikasi $T$-Unit.

Menurut Hunt (dalam Asnaeni 1998: 36), T-unit adalah suatu independen dengan subordinat dengan kalimat sederhana dalam teks selalu terdiri dari unit tunggal karena hanya terdiri dari satu kalimat independen".

2) Identifikasi hubungan semantik

Hubungan semantik dapat ditemukan dengan mengidentifikasi beberapa macam alat kohesi yang tampak dalam teks. Kehadiran referensi, subtitusi/pengganti, ellipsis, penghubung, pengulangan kata atau refetesi, leksikal dan alat lainnya, mengidentifikasi kehadiran hubungan langkah ini dalam pelajaran.

3) Penanaman kohesi yang teridentifikasi Identifikas klasifikasi tersebut ada beberapa bagian. Untuk melaksanakan langkah ini, dibuatlah kode-kode untuk mmpermudah pemahaman misalnya:

PRN : Pronominal ( referensi kata ganti)

KJG : Konjungsi (kata penghubung)

SBT : Subtitusi (penggantian)

4) Mendapatkam jumlah kohesi dan T-Unit pada setiap teks

Langkah selanjutnya dalam analisis kohesi atau menentukan jumlah kohesi dan T-Unit dalam setiap teks atau karangan untuk melengkapinya, jumlah kohesi dan T-Unit dapat dipermudah. Frekuesi kejadian kohesi didapatkan dengan rumus sebagai berikut:

(FK) Frekuensi kejadian $=\underline{\text { Jumlah }}$

$\underline{\text { kohesi }}$

Jumlah T-Unit

Sedangkan jumlah setiap jenis dari kohesi biasa didapatkan (FK) dari seiap jenis kohesi dapat dihitung dengan rumus seperti berikut: 


$$
F K^{\prime \prime} X "=\frac{j u m l a h " X "}{\text { jumlah T_Unit }}
$$

Dimana: "X" jumlah setiap kohesi

\section{METODE PENELITIAN}

\section{A. Variabel dan Desain Penelitian}

1. Variabel Penelitian

Variabel yang diamati dalam penelitian ini adalah variabel tunggal, yakni penggunaan kohesi pada karangan siswa SMP Muhammadiyah Takkalasi Kabupaten Barru.

2. Desain Penelitian

Penelitian ini didesain dengan menggunakan metode deskriptif kuantitatif. Deskripsi kuatitatif adalah mendeskrifsikan kenyataan-kenyataan yang ada dilapangan utamanya berhubungan dengan kemampuan siswa SMP Muhammadiyah Takkalasi Kabupaten Barru.

\section{B. Definisi Operasional Variabel}

Untuk menghindari adanya interprestasi yang berbeda mengenai istilah yang digunakan dalam variabel ini, maka perlu diberikan batasan sebagai berikut :

Analisis Kohesi adalah pengkajian tentang penggunaan kohesi dalam hubungan perkaitan antar proposisi yang dinyatakan secara eksplisit oleh unsur-unsur gramatikal dan semantik dalam wacana.

\section{Populasi dan Sampel \\ 1. populasi}

Populasi dalam penelitian ini adalah keseluruhan siswa kelas VIII SMP Muhammadiyah Takkalasi Kab. Barru sebanyak 25 orang.

\section{Sampel}

Sampel yang digunakan dalam penelitian ini adalah sampel total, melihat jumlah populasi penelitian ini kurang dari 100. Hal ini serupa dengan pendapat Arikunto (2002 :12) bahwa "apabila subjek populasi kurang dari 100 orang lebih baik diambil semua"

\section{Teknik Pengumpulan Data}

Untuk memperoleh data digunakan instrumen utama adalah karangan siswa.Dalam pembuatan karangan tersebut, siswa hanya menulis sebanyak 5 paragraf, dengan menentukan judul sendiri. Hal ini dimaksudkan untuk memberikan kebebasan kepada siswa agar mudah mengeluarkan kemampuan atau inspirasinya dalam mengarang sebab yang dianalis adalah penggunaan kohesi.

\section{E. Teknik Analisis Data}

1. Analisis Kohesi

Untuk menganalisis kohesi dilakukan dengan cara :

Pertama, menggambarkan jenis-jenis kohesi dalam karangan siswa.Jenis-jenis kohesi masing-masing karangan tersebut dikenali dan diketahui tipenya. Kemudian dipersentasekan untuk menjelaskan berapa komposisi jenis kohesi yang terjadi.

Kedua, menggambarkan frukuensi kejadian kohesi dalam karangan siswa.

Disini terjadi beberapa poin; (a) frekuensi terjadinya kohesi di tiap-tiap karangan, (b) frekuensi rata-rata kejadian kohesi dalam semua karangan; (c) frekuensi kejadian dari masing-masing jenis kohesi dalam tiap-tiap karangan; (d) frekuensi rata-rata kejadian/peristiwa dari masing-masing jenis kohesi dari semua karangan.

Ketiga, menggambarkan tingkat kesesuaian kohesi karangan siswa. Ini meliputi beberapa poin; (a) tingkatkeharmonisankohesi dari semua karangan;(b) tingkat rata-rata kesesuaian kohesi dari semua karangan; dan (c) proporsi/perbandingan karangan dengan 
tingkatan yang tinggi dari keseluruhan kohesi dan karangan dengan tingkatan rendah.

Analisis data untuk teori analisis kohesi dan analisis keselarasan kohesi dipergunakan metode analisis sesuai yang dikemukakan dengan Halliday dan Hasan seperti dari bab II. Bagian prosedur analisis kohesi dan bagian prosedur analisis keharmonisan kohesi.

Berdasarkan teori prosedur analisis kohesi dan analisis keharmonisan kohesi meliputi beberapa langkah digambarkan sebagai berikut.

a. Analisis Kohesi

Langkah-langkah yang digunakan dalam analisis kohesi seperti berikut ini:

1) Identifikasi T-Unit

2) Identifikasi hubungan semantik antar TUnit

3) Pelabelan/penamaan kohesi yang teridentifikasi

4) Memperoleh frekuensi perisriwa kohesi.

Tabel 1. Contoh Tabel Analisis Kohesi (Teks No:....)

\begin{tabular}{lll}
\hline T- Unit $\quad$ Hal yang diduga & Yang terduga & Tipe-tipe
\end{tabular}

Untuk mendapatkan frekuensi peristiwa kohesi di setiap teks yang dipergunakan rumus sebagai berikut:

$$
\mathrm{FK}=\frac{\sum k}{\sum T-U N I T}
$$

Dimana, $\mathrm{F}=$ Frekuensi perisriwa

$$
\mathrm{K}=\text { Kohesi }
$$

Untuk mendapatkan jumlah setiap jenis kohesi digunakan rumus :

$$
\mathrm{FK}=\frac{\sum \mathrm{X}}{\sum \mathrm{T}-\mathrm{Un} \text { it }}
$$

Dimana, $\mathrm{X}=$ nama jenis kohesi

Frekuensi rata-rata dari kohesi dalam keseluruhan karangan diperoleh dengan rumus:

$\mathrm{FK}=$ FK teks $1+\mathrm{FK}$ teks $2+\mathrm{Fk}$ teks $3+$ ...... Fk teks

$\mathrm{n}$

Dimana, $\mathrm{Fk}=$ frekuensi rata-rata kohesi dalam keseluruhan teks

$\mathrm{n}=$ jumlah teks
Untuk mengetahui rata-rata tingkat keharmonisan kohesi dalam jumlah karangan adalah dengan menggunakan rumus:

$\mathrm{KK}=\underline{\mathrm{KK} \text { teks } 1+\mathrm{KK} \text { teks } 2+\mathrm{KK} \text { teks } 3+}$ + KK teks

Dimana, $\mathrm{KK}=$ Rata-rata tingkat keharmonisan kohesi

$\mathrm{n}=$ Jumlah teks yang dianalisis

\section{HASIL PENELITIAN}

Pada bagian ini dibahas secara rinci mengenai hasil analisis sesuai dengan data yang diperoleh. Hasil analisis yang akan digambarkan yaitu pemakaian tipe kohesi dalam wacana.

\section{Tipe Kohesi}

Analisis data yang digambarkan dalam penggunaan tipe kohesi pada wacana siswa adalah dimaksudkan untuk menjawab 
pertanyaan, "bagaimana tipe kohesi yang dipergunakan oleh siswa pada wacana mereka?".Hasil analisis distribusi kohesi dalam wacana siswa yakni proporsi atau tingkat perbandingan kohesi dalam wacana siswa terdapat pada tabel 1 dan 2 . Tabel 1 menunjukkan jumlah tiap-tiap kohesi pada masing masing teks dimana jumlah total semua teks yang telah dianalisis. Tabel 2 menunjukkan proporsi tiap tiap tipe kohesi yang diungkapkan dalam persen.Pendeskripsian kedua table tersebut pada bagian pertama tipe kohesi yang terbentuk dalam wacana siswa.

Tabel 1

Distribusi Kohesi Karangan Siswa

\begin{tabular}{|c|c|c|c|c|c|c|c|c|c|c|c|c|}
\hline \multirow{2}{*}{$\begin{array}{l}\text { No } \\
\text { teks }\end{array}$} & \multirow{2}{*}{$\begin{array}{l}\text { Jumlah } \\
\text { kohesi }\end{array}$} & \multicolumn{11}{|c|}{ Jumlah kohesi dalam tiap tipe } \\
\hline & & Prn & Sbt & Elp & Kjg & Rpt & $\begin{array}{l}\mathrm{Sn} \\
\mathrm{m}\end{array}$ & Atn & $\begin{array}{c}\mathrm{Hp} \\
\mathrm{n}\end{array}$ & $\begin{array}{c}\mathrm{Mr} \\
\mathrm{n}\end{array}$ & Klk & $\mathrm{Ek}$ \\
\hline 1 & 84 & 12 & 2 & - & 35 & 26 & 3 & 2 & 2 & - & 2 & - \\
\hline 2 & 77 & 18 & 3 & - & 22 & 26 & 2 & 2 & - & - & - & 4 \\
\hline 3 & 60 & 7 & 1 & - & 21 & 23 & 3 & 2 & 2 & - & - & 1 \\
\hline 4 & 33 & 11 & 1 & - & 7 & 11 & 1 & 1 & 1 & - & - & - \\
\hline 5 & 34 & 10 & 2 & - & 13 & 7 & 1 & - & 1 & - & - & - \\
\hline 6 & 31 & 6 & 3 & - & 8 & 12 & - & 1 & 1 & - & - & - \\
\hline 7 & 25 & 6 & 2 & - & 6 & 7 & 2 & 1 & - & - & - & - \\
\hline 8 & 81 & 14 & - & 1 & 28 & 35 & 2 & 1 & - & - & - & - \\
\hline 9 & 49 & 9 & 1 & - & 16 & 17 & 1 & 2 & - & - & - & - \\
\hline 10 & 27 & 4 & 2 & - & 7 & 10 & 1 & 3 & - & - & - & - \\
\hline 11 & 75 & 14 & 1 & 1 & 22 & 34 & 1 & 1 & 1 & - & - & - \\
\hline 12 & 72 & 10 & - & 1 & 20 & 33 & 1 & - & 2 & - & 1 & 2 \\
\hline 13 & 71 & 14 & 2 & - & 24 & 21 & 3 & 3 & 2 & - & 1 & 1 \\
\hline 14 & 27 & 6 & 1 & - & 5 & 6 & 1 & - & - & - & - & - \\
\hline 15 & 60 & 17 & 1 & - & 21 & 20 & - & 1 & - & - & - & - \\
\hline 16 & 81 & 15 & 3 & 1 & 25 & 32 & 2 & 3 & - & - & - & - \\
\hline 17 & 82 & 21 & - & - & 29 & 30 & 1 & 1 & - & - & - & - \\
\hline 18 & 38 & 9 & 3 & - & 10 & 14 & 1 & 1 & 1 & - & - & - \\
\hline 19 & 20 & 3 & 1 & - & 3 & 12 & - & - & 1 & - & - & - \\
\hline 20 & 64 & 16 & 1 & - & 17 & 20 & 2 & 6 & 1 & - & 1 & - \\
\hline 21 & 56 & 16 & - & - & 22 & 15 & 1 & 1 & 1 & - & 1 & - \\
\hline 22 & 65 & 11 & 3 & 1 & 21 & 22 & - & 3 & 2 & - & - & 2 \\
\hline 23 & 70 & 14 & 1 & 2 & 18 & 25 & 1 & 2 & 3 & - & 1 & 3 \\
\hline 24 & 43 & 12 & 1 & - & 15 & 12 & - & 2 & 1 & - & - & - \\
\hline 25 & 76 & 20 & 1 & - & 25 & 29 & 1 & - & - & - & - & - \\
\hline$\overline{\text { JML }}$ & 1.410 & 295 & 36 & 7 & 440 & 501 & 31 & 39 & 22 & - & 8 & 14 \\
\hline $\mathbf{R}$ & 56,4 & 11,8 & 1,44 & 0,28 & 17,6 & 20,04 & 1,24 & 1,56 & $\mathbf{0 , 8 8}$ & - & 0,32 & 0,56 \\
\hline
\end{tabular}




\section{Catatan :}

JML : Jumlah

R : Rata-rata

Tabel 2

\section{Proporsi Kohesi Wacana Siswa}

\begin{tabular}{ccccccccccc}
\hline \multirow{2}{*}{$\begin{array}{c}\text { No } \\
\text { Teks }\end{array}$} & \multicolumn{10}{c}{ Tipe Kohesi } \\
\cline { 2 - 13 } & Sbt & Elp & Kjg & Rpt & Snm & Atn & Hpn & Klk & Ekv \\
\hline 1 & $14,28 \%$ & $2,39 \%$ & - & $41,67 \%$ & $30,95 \%$ & $3,57 \%$ & $2,38 \%$ & $2,38 \%$ & $2,38 \%$ & - \\
\hline 2 & $23,37 \%$ & $3,89 \%$ & - & $28,57 \%$ & $33,77 \%$ & $2,60 \%$ & $2,60 \%$ & - & - & $5,20 \%$ \\
\hline 3 & $11,66 \%$ & $1,67 \%$ & - & $35 \%$ & $38,33 \%$ & $5 \%$ & $3,33 \%$ & $3,33 \%$ & - & $1,77 \%$ \\
\hline 4 & $33,33 \%$ & $3,03 \%$ & - & $21,21 \%$ & $33,33 \%$ & $3,03 \%$ & $3,03 \%$ & $3,03 \%$ & - & - \\
\hline 5 & $29,41 \%$ & $5,88 \%$ & - & $38,24 \%$ & $20,58 \%$ & $2,94 \%$ & - & $2,94 \%$ & - & - \\
\hline 6 & $19,35 \%$ & $9,67 \%$ & - & $25,80 \%$ & $38,70 \%$ & - & $3,2 \%$ & $3,2 \%$ & - & - \\
\hline 7 & $24 \%$ & $8 \%$ & - & $24 \%$ & $28 \%$ & $8 \%$ & $4 \%$ & - & - & - \\
\hline 8 & $17,28 \%$ & - & $1,23 \%$ & $34,57 \%$ & $43,20 \%$ & $2,46 \%$ & $1,23 \%$ & - & - & - \\
\hline 9 & $18,36 \%$ & $2,04 \%$ & - & $32,65 \%$ & $34,69 \%$ & $2,04 \%$ & $4,08 \%$ & - & $4,08 \%$ & $2,04 \%$ \\
\hline 10 & $14,81 \%$ & $7,40 \%$ & - & $25,92 \%$ & $37,03 \%$ & $3,70 \%$ & $11,11 \%$ & - & - & - \\
\hline 11 & $18,66 \%$ & $1,33 \%$ & $1,33 \%$ & $29,33 \%$ & $45,33 \%$ & $1,33 \%$ & $1,33 \%$ & $1,33 \%$ & - & - \\
\hline 12 & $13,89 \%$ & - & $1,38 \%$ & $27,77 \%$ & $48,61 \%$ & $1,39 \%$ & - & $2,78 \%$ & $1,39 \%$ & $2,78 \%$ \\
\hline 13 & $19,71 \%$ & $2,82 \%$ & - & $33,80 \%$ & $29,57 \%$ & $4,22 \%$ & $4,22 \%$ & $2,82 \%$ & $1,40 \%$ & $1,40 \%$ \\
\hline 14 & $22,22 \%$ & $3,71 \%$ & - & $18,51 \%$ & $22,22 \%$ & $3,70 \%$ & - & - & - & - \\
\hline 15 & $28,33 \%$ & $1,67 \%$ & - & $35 \%$ & $33,33 \%$ & - & $1,67 \%$ & - & - & - \\
\hline 16 & $18,51 \%$ & $3,71 \%$ & $1,23 \% 30,86 \%$ & $39,51 \%$ & $2,47 \%$ & $3,70 \%$ & - & - & - \\
\hline 17 & $25,60 \%$ & - & - & $35,37 \%$ & $36,59 \%$ & $1,22 \%$ & $1,22 \%$ & - & - & - \\
\hline 18 & $23,68 \%$ & $7,89 \%$ & - & $26,31 \%$ & $36,84 \%$ & $2,63 \%$ & $2,64 \%$ & $2,64 \%$ & - & - \\
\hline 19 & $15 \%$ & $5 \%$ & - & $15 \%$ & $60 \%$ & - & - & $5 \%$ & - & - \\
\hline 20 & $25 \%$ & $1,56 \%$ & - & $26,56 \%$ & $31,25 \%$ & $3,13 \%$ & $9,38 \%$ & $1,56 \%$ & $1,56 \%$ & - \\
\hline 21 & $28,57 \%$ & - & - & $39,28 \%$ & $26,78 \%$ & $1,79 \%$ & $1,79 \%$ & $1,79 \%$ & - & - \\
\hline 22 & $16,92 \%$ & $4,62 \%$ & $1,54 \%$ & $32,30 \%$ & $33,84 \%$ & - & $4,62 \%$ & $3,07 \%$ & - & $3,07 \%$ \\
\hline 23 & $20 \%$ & $1,43 \%$ & $2,86 \%$ & $25,71 \%$ & $35,72 \%$ & $1,43 \%$ & $2,86 \%$ & $4,28 \%$ & $1,43 \%$ & $4,28 \%$ \\
\hline 24 & $27,91 \%$ & $2,33 \%$ & - & $34,88 \%$ & $27,91 \%$ & - & $4,65 \%$ & $2,33 \%$ & - & - \\
\hline 25 & $26,32 \%$ & $1,32 \%$ & - & $32,89 \%$ & $38,16 \%$ & $1,32 \%$ & - & - & - & - \\
\hline $\mathbf{J M L} \mathbf{5 3 6 , 1 7 \%} \mathbf{8 8 , 7 6 \%}$ & $\mathbf{9 , 5 7 \%} \mathbf{7 5 0 , 9 \%} \mathbf{1 . 2 1 4 . 2 4 \%} \mathbf{5 7 , 9 7 \%} \mathbf{7 3 , 0 4 \%} \mathbf{4 2 , 4 8 \%}$ & $\mathbf{1 2 , 2 \%} \mathbf{2 0 , 5 4 \%}$ \\
\hline $\mathbf{R}$ & $\mathbf{2 1 , 4 5 \%}$ & $\mathbf{3 , 5 6 \%}$ & $\mathbf{0 , 3 8 \%} \mathbf{3 0 , 3 6 \%}$ & $\mathbf{4 8 , 5 7 \%}$ & $\mathbf{2 , 3 9 \%}$ & $\mathbf{2 , 9 3 \%}$ & $\mathbf{1 , 6 9 \%}$ & $\mathbf{0 , 4 8 \%}$ & $\mathbf{0 , 8 2 \%}$ \\
\hline & & & & & & & & & & \\
\hline
\end{tabular}




\section{Catatan :}

$$
\begin{aligned}
& \text { JML : Jumlah } \\
& \text { R : Rata-rata }
\end{aligned}
$$

\section{a. Nama Identifikasi Kohesi}

PRN = Ponomina

Pronomina (kata ganti) terdiri dari: kata ganti orang, kata ganti penunjuk, kata ganti milik, kata ganti penanya, kata ganti penghubung, dan kata ganti tak tentu.

SBT $=$ Subtitusi

Subtitusi tediri dari: subtitusi nominal, subtitusi verbal, dan subtitusi kausal.

ELp = Elipsis

Elipsis terdiri dari: ellipsis nominal, elipsis verbal, dan elipsis kausal.

$\mathrm{KJG}=$ Konjungsi

Konjungsi terdiri dari: konjungsi kordinatif, konjungsi subordinatif, konjungsi kausal, konjungsi temporal, konjungsi adversative,dan konjungsi korelatif.

$$
\begin{aligned}
& \text { RPT }=\text { Repetisi } \\
& \text { SNM = Sinonim } \\
& \text { ATN = Antonim } \\
& \text { HPN = Hiponim } \\
& \text { EKV = Ekuvalensi } \\
& \text { MRN = Meronim } \\
& \text { KLK = Kolokasi }
\end{aligned}
$$

\section{b. Bentuk Tipe Kohesi}

Tabel 2 memperlihatkan bahwa sepuluh tipe dari sebelas tipe kohesi yang terdapat dalam karangan siswa masih ada satu tipe kohesi tidak terbentuk dalam karangan siswa yang tidak dimasukkan yaitu meronim.

Analisis kohesi juga dinyatakan dengan rata-rata perbandingan proporsi tipe kohesi dalam wacana siswa. Di sini memperlihatkan beberapa tipe secara jelas dibentuk dalam jumlah yang besar, jumlah sedang, dan beberapa jumlah dengan jumlah yang sangat kecil. Gambaran dari sebagian besar dari proporsi tiap-tiap kohesi dituliskan secara lengkappada daftar "rata-rata proporsi dalam wacana siswa" sebagai berikut:

1. Pronomina

$21,45 \%$

2. Subtitusi

$3,56 \%$

3. Elipsis

$0,38 \%$

4. Konjungsi

$30,36 \%$

5. Repetisi

$48,57 \%$

6. Sinonim

$2,39 \%$

7. Antonum

$2,93 \%$

8. Hiponim

$1,69 \%$

9. Kolokasi

$48 \%$

10.Ekuvalensi

$0,82 \%$

Daftar di atas memperlihatkan bahwa repetisi menunjukkan proporsi terbesar konjungsi dan pronominal di bawahnya. Walaupun demikian masih banyak tipe lain yang ditunjukkan lebih kecil dari kedua tipe tersebut. Dengan kata lain, repetisi, konjungsi, dan pronominal umumnya muncul pada setiap tipe kohesi dalam karangan siswa.

\section{c. Problema Kohesi}

Poin yang dilukiskan dari hasil analisis kohesi adalah ditemukanya masalah siswa dalam penggunaan kohesi seperti diungkap pada bahasan berikut:

\section{Repetisi}

Tabel 2 dan 3 menunjukkan bahwa RPT menduduki peringkat pertama pada karangan rata-rata antara 20,58\% (teks 5 ) sampai 48,61\% (teks 12) yang teridentifikasi. Contoh lain dapat dilihat dari kesalahan repetisi adalah sebagai berikut:

(a) Pada hari Senin yang akan datang semua siswa akan diliburkan selama tiga bulan yang membuat siswa merasa senang.

(b) Ketika Bilal dan Fajar tiba di rumahnya mereka memberitahu kepada ayah mereka bahwa mereka akan libur. 
(c) Pada suatu hari saya pergi berjalan ke suatu tempat dimana tempat itu sangatlah menyenangkan.

Berdasarkan ketiga data di atas, tampak bahwa kesalahan yang ada bukan hanya dari penggunaan repitisi, tetapi juga stuktur kalimatnya.

Penyusuna kata-kata seperti ini dikategorikan sebagai stuktur wacana yang membingunkan dan dapat diinterprestasikan bahwa wacana tersebut disusun tampa memperhatikan pola pembentukan/penyusunan kalimat yang baik. Selain itu, terdapat pengulangan yang seharusnya tidak perlu dilakukan, 'siswa' pada awal kalimat (1)diulang kembali di akhir kalimat. Demikian pula pada kalimat (2) dan (3), yaitu pengulangan kata 'mereka' dan 'tempat' yang seharusnya tidak perlu.

\section{Konjungsi}

Konjungsi (KJG) adalah salah satu tipe kohesi yang dipergunakan oleh siswa dalam karangannya.Namun, kesalahannya relative kecil seperti pada tabel 3. Proporsi KJG dalam karangan rata-tara $15 \%$ (teks 19) sampai $41,67 \%$ (teks 1) dari kohesi yang teridentifikasi. Adapun contoh kesalahan konjungsi adalah sebagai berikut:

(a) Pada sutu hari di sekolah, saya mengadakan acara penamatan siswa kelas tiga dan saya beserta teman-teman kami mengadakan rencana untuk pergi ke kassi dan teman-teman pun setuju dan akhirnya kami pun berangkat.

Kalimat diatas memperlihatkan bahwa penggunaan konjungsi kordinatif dan. Penggunaan konjungsi tersebut salah yang seharusnya tidak perlu terjadi

Karena telah ada konjungsi sebelumnnya. Misalnya konjungsi dan seharusnya dihilangkan salah satunya.

\section{Pronomina}

Pronominaadalah salah satu tipe kohesi yang terjadi dalam semua karangan siswa, seperti digambarkan pada tabel 3. Proporsi PRN menduduki peringkat di bawah tipe sebelumnya, dengan rata-rata $11,33 \%$ (teks 3 ) sampai $29,41 \%$ (teks 5) dari kohesi yang teridentifikasi. Adapun contoh penggunaan pronominal adalah sebagai berikut:

(a) Sekarang adalah penentuan pemilihan pemimpin yang bisa menjaga bangsanya dengan baik.

(b) Sehingga bangsa kita bisa tercipta keamanan, keadilan, dan kedamaian.

Penggunaan pronomina kita tidak konsekuen dengan penggunaan kalimat sebelumnya. Kita disini dapat ditafsirkan sebagai pembaca, pendengar atau orang lain.

(c) Jadi, kami pergi ke pantai untuk rekreasi.

(d) Sesampaiku di sana ternyata banyak orang asing yang mengunjungi tempat itu.

Keempat kalimat di atas dalam penggunaan pronomina 'kita' dan 'kami' dan ' $k u$ ' di sini akan mengacaukan interprestasi pembaca, sebab pronominal tersebut seakanakan disamakan penggunaannya. 'kita' tidak bisa diinterprestasikan pada subjek yang berbeda. 'kami' sebagai subjek pelaku sedangkan ' $k u$ ' dan 'kita' bisa ditafsirkan sebagai orang ketiga jamak yang berarti pelaku lain.

\section{Antonim}

Hasil analisis membuktikan bahwa penggunaan ATN tidak memiliki kesalahan seperti tipe yang diungkap senbelumnya. Proporsi rata-rata semua karangan sejumlah $1,22 \%$ (teks 17) sampai 9,38\% (teks 20). Dari dua puluh lima wacana, sebanyak dua puluh yang menggunakan tipe tersebut.

\section{Sinonim}

Dalam tabel 2 dan 3, tipe kohesi yang digunakan siswa salah satunya adalah 
sinonim. Penggunaannya menduduki proporsi rata-rata dari $1,22 \%$ (teks 17) sampai $3,70 \%$ (teks 14) yang teridentifikasi, dari dua puluh lima wacana, sebanyak dua puluh yang menggunakan tipe tersebut.

\section{Subtitusi}

Kejadian SBT pada karangan siswa memperoleh proporsi rata-rata $1,32 \%$ (teks 25) sampai $9,67 \%$ (teks 6). Dari dua puluh lima wacana, sebanyak dua puluh satu yang mempergunakan tipe tersebut. Proporsi ratarata kejadian dari semua karangan, yaitu $3,56 \%$ lebih rendah dari tipe yang telah disebutkan di atas. Kondisi seperti ini telah dinyatakan secara tidak langsung bahwa masih ada siswa yang tidak mengenal penggunaan subtitusi.

\section{Hiponim}

Kejadian HPN pada karangan siswa memperoleh proporsi rata-rata $1,33 \%$ (teks 11) sampai $4,28 \%$ (teks 23). Dari dua puluh lima wacana, sebanyak lima belas yang mempergunakan tipe kohesi tersebut. Proporsi rata-rata kejadian dari semua karangan, yaitu 1,69 yang teridentifikasi.

\section{Kolokasi}

Tipe kohesi KLK kejadiannya adalah antara $1,39 \%$ (teks 12) sampai 4,08\% (teks 9) proporsi rata-rata KLK dalam karangan siswa yang telah dianalisis adalah $0,48 \%$. Penggunaan KLK masih belum dikenal oleh sebagian besar siswa, sebab kenyataannya hanya digunakan oleh enam siswa.

\section{Ekuvalensi}

Tipe kohesi EKV jumlah kejadiannya antara 1,40\% (teks 13) sampai 5,20\% (teks 2). Proporsi rata-rata EKV dalam karangan siswa yang telah dianalisis adalah 0,82\%. Penggunaan EKV masih belum dikenal oleh sebagian besar siswa, sebab kenyataannya hanya digunakan oleh tujuh siswa dalam karanganya.

\section{Elipsis}

Dari ketiga jenis ELP, yakni ELP nominal, ELp verbal, ELP kausal, kejadiannya secara keseluruhan hanya berjumlah $0,38 \%$ dari total kohesi yang teridentifikasi, penggunaan elipsis ini ditemukan pada enam karangan, secara jelas dapat dikemukakan bahwa tipe ini belum dikenal oleh sebagian siswa sehingga jarang menggunakan dalam tulisannya.

\section{SIMPULAN}

Berdasarkan hasil pembahasan di atas berikut ini dideskripsikan kesimpulan yang diperoleh.

Studi ini menyatakan kohesi dalam wacana tulis yang dihadirkan dalam wacana atau karangan siswa kelas VIII SMP Muhammadiyah Takkalasi Kab. Barru. Pernyataan kohesi dispesifikasikan ke dalam aspek tipe-tipe kohesi. Dalam hubungannya dengan spesifikasi tersebut, studi ini dimaksudkan untuk menentukan jawaban dari persoalan kohesi, yaitu tipe-tipe kohesi dalam karangan pelajar.

Sebagian besar mereka menggunakan enam sampai delapan tipe. Secara umum tipetipe yang digunakan oleh semua pelajar tiga jenis tipe: Repetisi (RPT), Konjungsi (KJG), dam Pronomina (PRN). Proporsi ketiga tipe tersebut lebih besar dibandingkan dengan tipe-tipe lainnya. Proporsi rata-rata untuk repetisi dalam wacana siswa adalah

48,57\%, konjungsi adalah 30,36\%, dan pronominal dengan proporsi rata-rata $21,45 \%$.

\section{DAFTAR PUSTAKA}


Achmadi. 1990. Analisis Wacana. Ujung

Pandang: FBS IKIP Ujung Pandang.

Akhadiah, Sabarti. 1998. Pembinaan Kemampuan Menulis Bahasa IKIP. Jakarta: Erlangga.

Alwi, Hasan. dkk. 2000. Tata Bahasa Baku Bahasa Indonesia. Jakarta: Balai Pustaka.

Arikunto, Suharsimi. 2002. Posedur

Penelitian. Jakarta: Rineka Cipta .

Asnaeni, M. 1998. Kohesi dan Koherensi dalam Karangan Deslriptif Siswa SMU Negeri 2 Maros. Makassar: Skripsi FBS UNM.

Depdikbud. 1981. Buku Laporan Sekolah Menengah. Kanwil Departemen Pendidikan dan Kebudayaan SulSel.

Depdikbud.2001. Kamus Besar Bahasa

Indonesia. Jakarta: Balai Pustaka.

Gie, The Liang. 1992. Terampil Mengarang.

Yokyakarta: Andi Yokyakarta.

Halliday, M.A.K, \& Hasan, Ruqaya. 1976. Cohesion in English. Yokyakarta: Gajah Mada Universiti Press.

Hariyanto.1994. Cohesionin Deskriptive Discourse Written by the sixth Semester Student of the .English Dapartemen of FPBS IKIP Ujung Pandang. Malang: Program Pasca Sarjana IKIP Malang.

Hasan, Ruqaya. 1984. 1989. Keharmonisan Kohesi. Yokyakarta: Gajah Mada University Press

Irawan. 1997. Kohesi dalam Kumpulan Puisi Sukma Laut Karya Aspar (Suatu Analisis Wacana ). Makassar: Skripsi FBS UNM.
Junus, A.Muhammad.2002. Sintaksis Bahasa Bugis. Makassar: UNM.

Kridaklaksana, Hari Murti. 1993. Kamus Linguistik. Jakarta: Gramedia.

Macmued, Zaini. 1976. Dasar-dasar Komposisi Majalah Pengajaran Bahasa dan Sastra. Jakarta: Pusat Pembinaan dan Pengembangan Bahasa.

Nafiah.A.Hadi. 1981. Anda Ingin Jadi

Pengarang?. Surabaya: Usaha Nasional.

Poerwadarminta, W.J.S. 1984. ABC Karang

Mengarang. Jakarta: Balai Pustaka.

Ramlan, M. 1993. Paragraf. Alur piker dan Kepaduannya dalam Bahasa Indonesia Yokyakarta. Yokyakarta: Andi Ofiset.

Suhaebah, Ebah, dkk. 1996. Penyulihan sebagai Alat Kohesi Dalam Wacana. Jakarta: Pusat Pembinaan dan Pengembangan Bahasa.

Sumadi, dkk. 1998. Kohesi dan Koherensi dalam Wacana Naratif Bahasa Jawa. Jakarta: Balai Pustaka.

Tarigan, Henry Guntur. 1987. Menulis Sebagai Keterampilan Berbahasa. Bandung: Angkasa Bandung. 